\title{
Structure modification and extracellular polymeric substances conversion during sewage sludge biodrying process
}

\author{
Lu Cai $^{\mathrm{a}, \mathrm{b}}$, Thomas Krafft ${ }^{\mathrm{b}}$, Tong-Bin Chen ${ }^{\mathrm{c}, *}$, Ding Gao ${ }^{\mathrm{c}}$, Li Wang ${ }^{\mathrm{b}}$ \\ ${ }^{a}$ Faculty of Architectural, Civil Engineering and Environment, Ningbo University, Ningbo, China \\ ${ }^{\mathrm{b}}$ Faculty of Health, Medicine and Life Sciences, Maastricht University, Maastricht, The Netherlands \\ ${ }^{\mathrm{C}}$ Center for Environmental Remediation, Institute of Geographic Sciences and Natural Resources Research, Chinese Academy of Sciences, Beijing, China
}

\section{H I G H L I G H T S}

- $62 \%$ of total water removal occurred during the first thermophilic phase.

- Biodrying creates a porous and stratified structure with smoother edges.

- Aromatic proteins and soluble microbial byproducts in EPS are greatly degraded.

- The thermophilic phase is most critical in transforming bound water to free water.

- Biodrying modifies the sludge structure and improves dewaterability.

\section{A R T I C L E I N F O}

\section{Article history:}

Received 3 April 2016

Received in revised form 21 May 2016

Accepted 24 May 2016

Available online 26 May 2016

\section{Keywords:}

Biodrying

Extracellular polymeric substances

Free water

Morphological change

Sewage sludge
G R A P H I C A L A B S T R A C T

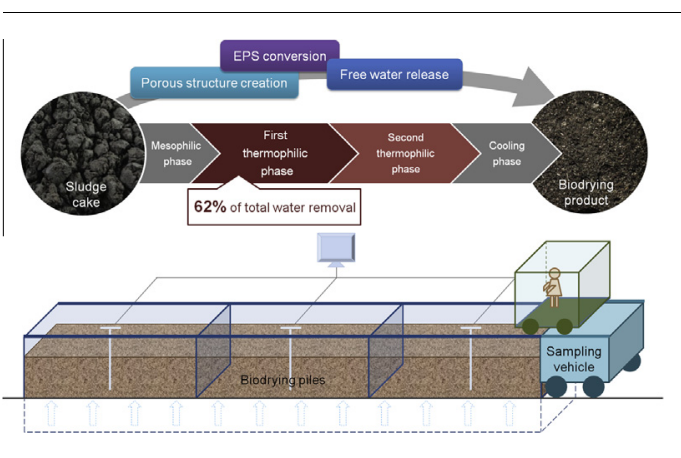

\begin{abstract}
A B S T R A C T
Biodrying, an economical and energy-saving biomass waste treatment, removes water from waste using the biological heat generated by organic matter degradation. Technical limitations associated with dewatering complicate the biodrying of sewage sludge. This study investigated the sludge alteration associated with its water removal, focusing on sludge form, extracellular polymeric substances, and free water release. An auto-feedback control technology was used for the biodrying; a scanning electron microscope was used to record the morphological change; three-dimensional excitation-emission matrix fluorescence spectroscopy was used to analyze extracellular polymeric substances (EPS) variation, and time domain reflectometry was used to assess the free water release. Over the 20-day biodrying, there was a $62 \%$ water removal rate during the first thermophilic phase. Biodrying created a hollow and stratified sludge structure. Aromatic proteins and soluble microbial byproducts in the EPS were significantly degraded. The thermophilic phase was the phase resulting in the greatest free water release.
\end{abstract}

(c) 2016 Elsevier Ltd. All rights reserved.

\footnotetext{
* Corresponding author at: Center for Environmental Remediation, Institute of Geographic Sciences and Natural Resources Research, Chinese Academy of Sciences, 11A Datun Road, Beijing 100101, China.

E-mail address: chentb@igsnrr.ac.cn (T.-B. Chen).
}

\section{Introduction}

Dewatering sewage sludge is of major interest in sludge treatment and disposal. Mechanically dewatered sewage sludge cake contains $80-85 \%$ moisture in most WWTPs, despite dewatering improvements during the past few decades (Huang et al., 2015). An additional dewatering step is often needed, to reduce moisture content to a level that enables sewage sludge disposal. According 
to the disposal standards of sludge from municipal wastewater treatment plant in China, the moisture content of sewage sludge adopted for sanitary landfills and land use should be less than $60 \%$, and it should be less than $45 \%$ if the sludge is used as barrier material in landfill cover systems (Liu et al., 2013). For incineration, though sewage sludge with $60-80 \%$ moisture content can be co-incinerated, sewage sludge (around $14 \mathrm{MJ} \mathrm{kg}^{-1}$ dry mass) with $50 \%$ moisture content can achieve self maintaining incineration without additional fuel (Stasta et al., 2006).

Drying technology reduces the moisture content of a matrix by the application of heat, and produces dried outputs of desired characteristics (Velis et al., 2009). However, thermal dryers using external energy have been used for sludge dewatering, which do not rely on microbial produced heat, leading to high costs (Kurt et al., 2015). Compared to thermal drying, no extra heat is required for biodrying (He et al., 2013). Biodrying, an alternative way to treat biomass waste, is an economical and energy-saving method that removes water from waste material using the microbial heat originating from organic matter degradation, which is based on a process similar to composting (Winkler et al., 2013). The moisture reduction during biodrying is as follows: water molecules evaporate from the SSBM surface into the air, after which the evaporated water is transported and removed by airflow (Velis et al., 2009). The main biodrying mechanism is convective evaporation, which utilizes heat produced from the biodegradation of organic matter and is facilitated by mechanically controlled aeration (NavaeeArdeh et al., 2010). The major difference of biodrying from composting is that the major purpose of composting relates to biological stability and maturity, while the one of biodrying is to achieve the highest water removal in a short duration (Rada et al., 2009). Researchers have analyzed the energy balance of a biodrying process (He et al., 2013). The kinetics of volatile solids biodegradation and the simultaneous effect of initial moisture content and airflow rate on biodrying performance have been studied (Huiliñir and Villegas, 2015). Mechanical controls, such as aeration and turning, propel the process. The effects of airflow and turning regime on bio-drying of sewage sludge indicated that forced aeration improved evaporation, while frequent turning hindered the biodrying (Zhao et al., 2010; Cai et al., 2012). Bacterial analysis showed that during the thermophilic phase, in which Acinetobacter and Bacillus were the dominant genera, the rates of water evaporation, water generation, and organic degradation peaked (Cai et al., 2016). Biodrying has also been used for post-treatment of anaerobically digested sludge, and it is found that some dominant Firmicutes seemed to relate with the organic degradation ( $\mathrm{Li}$ et al., 2015). Biodried material can be considered as a solid recovered fuel-like product, leading to a better respirometric index (Rada and Ragazzi, 2014). The SSBM moisture content is not efficiently decreased during the initial sewage sludge biodrying phase; however, after the self-heating of the biodrying pile, the SSBM moisture content can be significantly reduced (He et al., 2013).

Understanding the factors influencing sewage sludge dewaterability can help improve it (Raynaud et al., 2012). Poor dewaterability is often associated with the presence of extracellular polymeric substances (EPS) or bound water trapped in the sludge flocs (Li and Yang, 2007). EPS is an important constituent of sludge flocs, and contributes to its surface properties, formation, and major organic fraction (Basuvaraj et al., 2015). Loosely bound EPS content negatively impacts bioflocculation and sludge dewatering (Li et al., 2014). EPS composition is complex, and depends on the bacterial species and growth conditions (Yu et al., 2011); as such, EPS is a critical factor in determining sludge dewaterability (Li and Yang, 2007). The fluorescence compounds of EPS can be determined using three-dimensional excitation-emission matrix (EEM) fluorescence spectroscopy (Zhen et al., 2012). Chen et al. (2003) described five EEM spectra regions, which delineate differences in readily degradable materials (simple aromatic proteins and soluble microbial by-product-like) and less degradable (fulvic acidlike and humic acid-like) materials in EPS.

Bound water is another key factor affecting dewaterability (Song et al., 2014). Water in sewage sludge takes the form of bound water and free water. The bound water is defined as the portion of moisture that cannot be removed by mechanical means (Wu et al., 1998). Amount of bound water presented in the initial SSBM may change during the biodrying process, potentially affecting the dewaterability. Time domain reflectometry (TDR) has been used to assess the alteration of the dielectric constant, indicating the transformation of bound water to free water (Schwartz et al., 2008). At $20^{\circ} \mathrm{C}$, the dielectric constants of free water, bound water, air, and solid particles (including organic matter) are approximately $81,3-4,1$, and 3-12, respectively (Boyarskii et al., 2002). Because the dielectric constant of free water is much larger than other biodrying material constituents, determining free water content by measuring the dielectric constant is reasonable (Noborio, 2001). As such, at constant moisture content, the transformation from bound water to free water can be signaled by an increasing dielectric constant.

The biodrying technique has been widely used for sludge treatment; however, dewatering limitations remain, and understanding EPS variations and the transformation from bound water to free water during biodrying may benefit the process. Therefore, this research investigated sewage sludge structural changes, including sludge form, EPS, and free water release to study the effect of biodrying on water removal.

\section{Materials and methods}

\subsection{Materials}

Mechanically dewatered sewage sludge cake was collected from a sewage sludge treatment plant (Shanghai, China). Sawdust, with a $2 \mathrm{~mm}$ average diameter, was bought from a timber mill, and the biodrying product was collected at the end of a sludge biodrying period, both the sawdust and the biodrying product were used bulking agents. To avoid differences in physical structures, improved mixer and turning machine (CTB, GreenTech Environmental Engineering Co., Beijing, China) were used to homogenize the SSBM. The sewage sludge, sawdust, and biodrying product were uniformly mixed at a mass ratio of $6: 1: 3$ to constitute the SSBM; the SSBM was then loaded into a tank for biodrying. The key parameters of the sewage sludge and the initial SSBM were as follows, respectively: the moisture content was $80.2 \%$ and 62.3\%; bulk density was $1.03 \mathrm{~g} \mathrm{~cm}^{-3}$ and $0.75 \mathrm{~g} \mathrm{~cm}^{-3}$; and volatile solid content was $62.1 \%$ and $79.5 \%$.

\subsection{Experimental procedure}

\subsubsection{Sewage sludge biodrying}

The tank used for this study was $15 \mathrm{~m}$ long, $5 \mathrm{~m}$ wide, and $2 \mathrm{~m}$ high. The tank was divided into three compartments to allow for three replicate tests; each test biodrying pile was $5 \mathrm{~m}$ long, $5 \mathrm{~m}$ wide and $1.8 \mathrm{~m}$ high (Fig. 1). Temperature and oxygen sensors (CTB, GreenTech Environmental Engineering Co., Beijing, China) were installed in the center of each test biodrying pile to monitor temperature and oxygen concentrations. The biodrying pile in each tank area was monitored using an auto-feedback control technology for biodrying (CTB, GreenTech Environmental Engineering Co., Beijing, China); this technology allowed for aeration adjustments and the need for mechanical turning based on pile temperature and oxygen concentration. Fig. 1 shows the experimental equipment. 


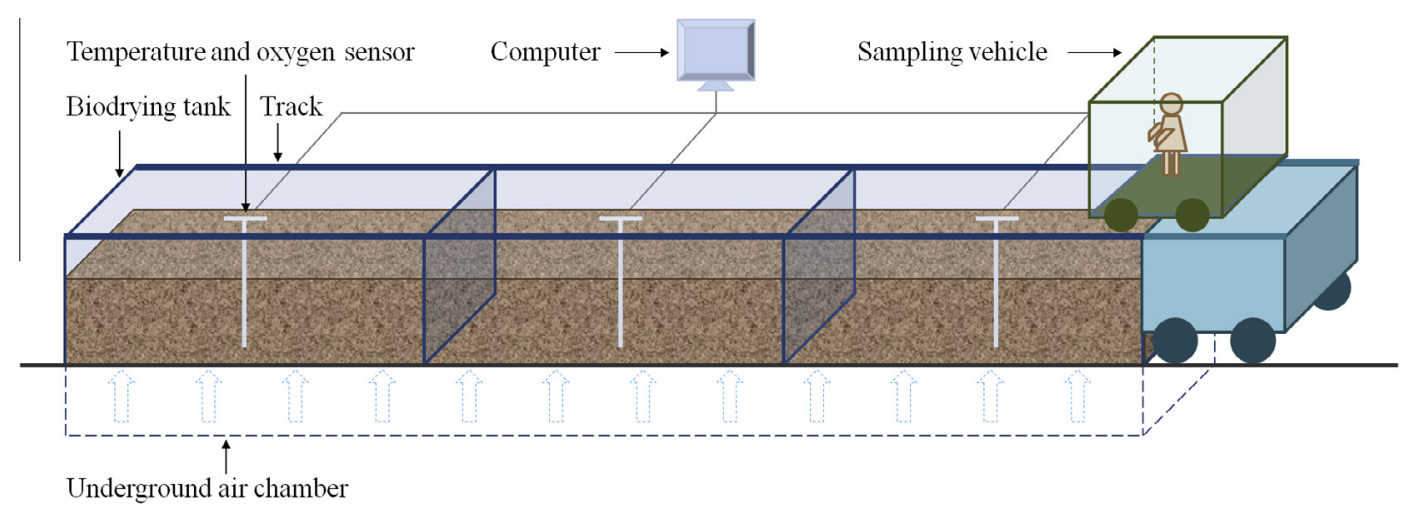

Fig. 1. Structure of the sewage sludge biodrying test area.

During the 20-day biodrying period, an air blower intermittently aerated the three test piles, and the piles were mechanically turned four times (on days 9,12,15, and 18). Temperature monitoring indicated that the piles experienced a mesophilic phase (temperature increasing phase), an initial thermophilic phase (with a pile temperature higher than $50^{\circ} \mathrm{C}$ ), a second thermophilic phase (after the turning of the pile on day 9 , the pile temperature dropped and then rebounded), and a cooling phase. To ensure the representativeness and avoid damaging the biodrying piles, samples were collected from the top, middle, and bottom of the piles, and then mixed for analysis (Zhao et al., 2010). Samples were collected using a remote-controlled sampling vehicle, running on tracks over the piles (CTB, GreenTech Environmental Engineering Co., Beijing, China).

\subsubsection{Water removal rate calculation}

Assuming that the change in the pile weight is driven by organic degradation and water removal, and assuming ash content does not change during biodrying (Cai et al., 2012), the total water mass of the biodrying pile on day $t$ is:

$M_{H_{2} O, t}=M_{0} \frac{\left(1-M C_{0}\right)\left(1-V S_{0}\right)}{\left(1-M C_{t}\right)\left(1-V S_{t}\right)} M C_{t}$

In this expression, $M_{\mathrm{H}_{2} \mathrm{O}, t}$ is the total water mass of the pile on day $t(\mathrm{~kg}) ; M_{0}$ is the pile weight on day $0(\mathrm{~kg}) ; M C_{0}$ and $M C_{t}$ represent the moisture content of SSBM on day 0 and day $t$, respectively; $V S_{0}$ and $V S_{t}$ represent the volatile solid content of SSBM on day 0 and day $t$, respectively.

The water removal rate is calculated as follows:

$R_{w}=\frac{M_{\mathrm{H}_{2} \mathrm{O}, t-1}-M_{\mathrm{H}_{2} \mathrm{O}, t}}{\Delta M_{\mathrm{H}_{2} \mathrm{O}}} \cdot 100 \%$

$R_{w}$ is the water removal rate per day (\%); $M_{\mathrm{H}_{2} \mathrm{O}, t-1}$ is the total water mass of the pile on day $t-1(\mathrm{~kg}) ; M_{\mathrm{H}_{2} \mathrm{O}, t}$ is the total water mass of the pile on day $t(\mathrm{~kg}) ; \Delta M_{\mathrm{H}_{2} \mathrm{O}}$ is the total water removal of the pile after biodrying ( $\mathrm{kg})$.

The SSBM moisture content and volatile solid content were analyzed using methods described by the U.S. Department of Agriculture and the U.S. Composting Council (2001).

\subsubsection{Morphological analysis}

To investigate each phase's morphological changes and to analyze the biological effect on the SSBM, besides thermal drying effect, biodrying samples were compared with samples dried in an air oven. Samples were collected as follows.

First, biodrying samples were collected for morphological analysis throughout the experimental period. SSBM samples without biodrying were collected on day $0\left(20^{\circ} \mathrm{C}\right.$, moisture con- tent $=62.3 \%$, during the first thermophilic phase on day $4\left(56{ }^{\circ} \mathrm{C}\right.$ moisture content $=59.8 \%)$ and day $8\left(70^{\circ} \mathrm{C}\right.$, moisture content $=52.2 \%$, and during the second thermophilic phase on day $12\left(60^{\circ} \mathrm{C}\right.$, moisture content $\left.=45.5 \%\right)$. Resulting product was collected on day $20\left(20^{\circ} \mathrm{C}\right.$, moisture content $\left.=39.2 \%\right)$. These biodrying samples were named B62, B60, B52, B45, and B39 based on moisture content.

Second, thermal drying testing was conducted in a way that mirrored the biodrying sampling, to facilitate comparisons between the two drying methods. An initial SSBM sample was collected on day $0\left(20^{\circ} \mathrm{C}\right)$ and sterilized using ultraviolet to avoid microbial interference. The sterilized sample was dried in an air oven. When the sample temperature reached $56^{\circ} \mathrm{C}$, the sample was dried until its moisture content decreased to approximately $60 \%$. A subsample of this sample was then further dried until its temperature reached $70^{\circ} \mathrm{C}$; subsample drying at this temperature continued until the moisture content decreased to approximately $52 \%$. A subsequent subsample was then dried at a lower temperature until the temperature fell to $60{ }^{\circ} \mathrm{C}$; the subsample was dried at this temperature until its moisture content decreased to approximately $45 \%$. A final subsample then continued to be dried at a lower oven temperature until its temperature fell to $20^{\circ} \mathrm{C}$; it was then dried at this temperature until its moisture content reached approximately $39 \%$. These thermal drying samples were labeled as T60, T52, T45, and T39, again based on their moisture content values.

Table 1 lists the moisture contents of the analyzed samples. All samples resulting from both drying methods were cooled to $20^{\circ} \mathrm{C}$ and then analyzed using a scanning electron microscope (SEM) (KYKY, Beijing, China). Three replicates were observed during SEM analysis.

Table 1

Moisture content of samples for scanning electron microscopy treated using biodrying and thermal drying.

\begin{tabular}{cllll}
\hline Treatment & Sample & $\begin{array}{l}\text { Sampling } \\
\text { time }(\mathrm{d})\end{array}$ & $\begin{array}{l}\text { Temperature when } \\
\text { collected }\left({ }^{\circ} \mathrm{C}\right)\end{array}$ & $\begin{array}{l}\text { Moisture } \\
\text { content (w.b. }, \text {,\%) }\end{array}$ \\
\hline Biodrying & B62 & 0 & 20 & $62.3 \pm 0.3$ \\
& B60 & 4 & 56 & $59.8 \pm 0.7$ \\
& B52 & 8 & 70 & $52.2 \pm 0.9$ \\
& B45 & 12 & 60 & $45.5 \pm 0.9$ \\
& B40 & 16 & 42 & $40.3 \pm 1.0$ \\
& B39 & 20 & 20 & $39.2 \pm 1.1$ \\
Thermal & T60 & N/A & 56 & $60.1 \pm 0.2$ \\
drying & T52 & N/A & 70 & $51.8 \pm 0.3$ \\
& T45 & N/A & 60 & $45.1 \pm 0.3$ \\
& T39 & N/A & 20 & $38.9 \pm 0.3$ \\
\hline
\end{tabular}

a w.b. refers to a wet basis. 


\subsubsection{Extracellular polymeric substances determination}

SSBM samples for EPS testing were collected on day $0\left(20^{\circ} \mathrm{C}\right.$, moisture content $=62.3 \%$ ), during the first thermophilic phase on day $4\left(56{ }^{\circ} \mathrm{C}\right.$, moisture content $\left.=59.8 \%\right)$ and day $8\left(70{ }^{\circ} \mathrm{C}\right.$, moisture content $=52.2 \%)$, the second thermophilic phase on day $12\left(60{ }^{\circ} \mathrm{C}\right.$, moisture content $=45.5 \%)$, the cooling phase on day $16\left(42{ }^{\circ} \mathrm{C}\right.$, moisture content $=40.3 \%$ ), and the biodrying product on day 20 $\left(20^{\circ} \mathrm{C}\right.$, moisture content $\left.=39.2 \%\right)$. These biodrying samples were named B62, B60, B52, B45, B40, and B39, and were collected at the same time as the sampling described in Section 2.2.3.

Next, a $1 \mathrm{~g}$ SSBM sample was mixed with $3 \mathrm{ml}$ distilled water; the mixture was centrifuged at $12,000 \mathrm{r} \mathrm{min}^{-1}$ at $4{ }^{\circ} \mathrm{C}$ for $15 \mathrm{~min}$. Then, ultrasonication was applied for $5 \mathrm{~min}$. The mixture was heated at $80^{\circ} \mathrm{C}$ for $10 \mathrm{~min}$, and then centrifuged again at $8000 \mathrm{r} \mathrm{min}^{-1}$ at $4{ }^{\circ} \mathrm{C}$ for $10 \mathrm{~min}$ (Guo et al., 2014). Supernatant was collected, diluted by a factor of 30 , and then analyzed using EEM fluorescence spectroscopy with a spectrofluorometer (Varian, Palo Alto, USA) at $20^{\circ} \mathrm{C}$. Excitation and emission slits were maintained at $5 \mathrm{~nm}$ and the scanning speed was $1200 \mathrm{~nm} \mathrm{~min}^{-1}$. All the samples were measured for three times. Plotting was done using Origin 9.0 (OriginLab, Northampton, USA).

\subsubsection{Dielectric constant measurement}

To investigate the transformation from bound water to free water, biodrying samples were collected at $20^{\circ} \mathrm{C}$ (without biodrying), $30^{\circ} \mathrm{C}, 40^{\circ} \mathrm{C}, 50^{\circ} \mathrm{C}, 60^{\circ} \mathrm{C}$, and $70^{\circ} \mathrm{C}$, and were named $\mathrm{DC} 20$, DC30, DC40, DC50, DC60, and DC70, respectively, based on collection temperature. These samples were collected during the mesophilic phase and thermophilic phase, when the heat most significantly affected water transformation. Free water would be evaporated during the biodrying process while the remaining bound water was still in the SSBM. Therefore, before measuring the dielectric constant, deionized water should be added into the samples to adjust the moisture content to 62\% (the initial SSBM moisture content) to return the evaporated free water into the SSBM. All samples were cooled to $20^{\circ} \mathrm{C}$ before the dielectric constant was measured using the TDR (Campbell Scientific, Inc., Logan, USA), and three replicates were conducted.

To calculate the bound water contents of SSBM in different phases, the mathematical correlation between the free water content and dielectric constant should be established as follows. Firstly, SSBM were oven-dried at $75^{\circ} \mathrm{C}$ to destroy the bound water layers (Vesilind, 1994). Secondly, the deionized water was added into the dried SSBM to adjust the moisture content to 65\% (to cover the initial $62 \%$ moisture content) to ensure that the total water in the SSBM is free water (named as $\mathrm{SSBM}_{\text {free }}$ ). After that, the $\mathrm{SSBM}_{\text {free }}$ with $65 \%$ moisture content was oven-dried gradually until it decreased to approximately 51\% moisture content, during which the moisture content and the corresponding dielectric constant were measured. Then the data can be used for mathematical correlation.

Topp et al. proposed a 3rd order polynomial as an empirical relationship, which has broad applicability (Nadler et al., 2002). Thus, the data generated in the present study were fitted in a 3rd order polynomial equation to build the relationship between the dielectric constant and free water content. Origin 8.0 was used to construct the equation. The free water contents under different dielectric constants can be calculated via the relationship equation. Therefore, the bound water contents in different phases can be calculated from the total moisture content and free water contents as follows:

$M C_{\text {bound }}=M C_{\text {total }}-\frac{M C_{\text {purefree }} \cdot \rho_{\text {purefree }}}{\rho}$
$M C_{\text {bound }}$ is the bound water content in SSBM (\%); $M C_{\text {total }}$ is the total moisture content in SSBM (\%); $M C_{\text {purefree }}$ is the free water content in $\operatorname{SSBM}_{\text {free }}(\%) ; \rho_{\text {purefree }}$ is the bulk density of $\operatorname{SSBM}_{\text {free; }}$; and $\rho$ is the bulk density of SSBM.

\section{Results and discussion}

\subsection{Water removal rate}

The SSBM moisture content decreased from $62.3 \%$ to $39.2 \%$ and the volatile solid content decreased from $79.5 \%$ to $73.1 \%$ over the 20-day biodrying period (Fig. 2b). Fig. 2a presents the water removal rate, represented as the percentage of daily water removal to total water removal. During the initial mesophilic phase, the water removal rate increased gradually, and it significantly

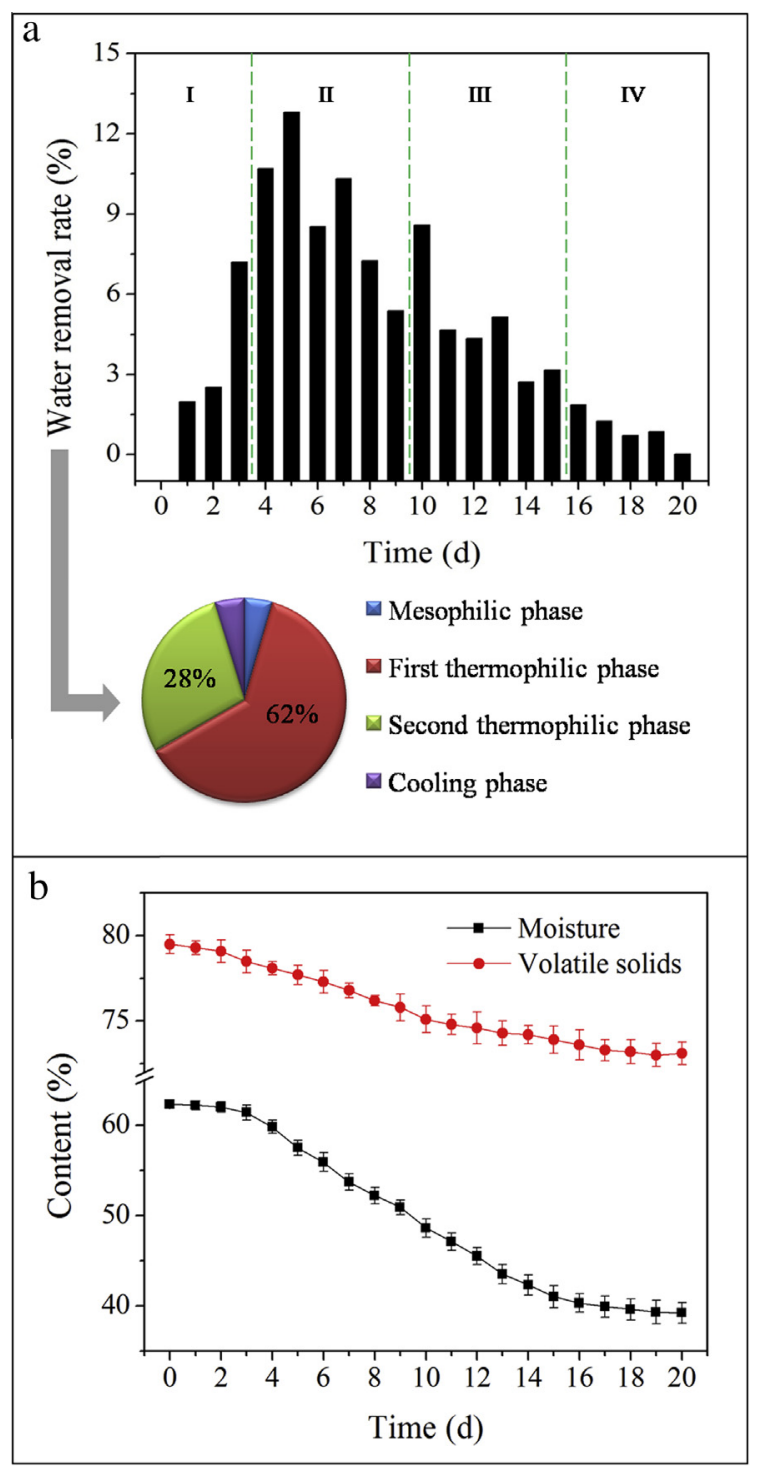

Fig. 2. Water removal rate, moisture content, and volatile solids in sewage sludge biodrying material. a - Water removal rate during the sewage sludge biodrying process. The areas separated by dashed lines are: I-mesophilic phase, II-first thermophilic phase, III-second thermophilic phase, and IV-cooling phase. b Moisture content and volatile solids content of the sewage sludge biodrying material. 
increased from $2.5 \%$ to $7.2 \%$ when the pile entered the first thermophilic phase on day 3 . Water removal peaked on day 5 at $12.8 \%$, and then decreased to the final value of $0.02 \%$ on day 20 . Water removal during the 7-day long first thermophilic phase accounted for $62 \%$ of the total water removal; $28 \%$ of water removal occurred during the 6-day long second thermophilic phase. As such, $90 \%$ of the total water removal occurred during these two phases.

\subsection{Sludge structure}

Fig. S1 in supplementary material shows the morphological results of the biodrying samples. The SEM images showed that the structure of initial biodrying sample (Fig. S1, B62) was more compact and viscous than the structure of the final biodrying product (Fig. S1, B39). The final biodrying product also had a clear stratified structure that the initial biodrying sample did not. The biodrying sample surfaces became hollower as the biodrying proceeded; the hollow area was evenly distributed at the end of biodrying.

The morphological features of the biodrying samples were also compared with those of thermal drying samples at the same temperatures at the same moisture content. SEM images showed that the edges of the stratified structures in the final thermal drying product (Fig. S1, T39) were more distinct than in the biodrying product (Fig. S1, B39). This indicates that the thermal effect creates a hollow and stratified structure, and the microbial activities keep the structure less angular with smoother edges and leave many pores.

\subsection{Extracellular polymeric substances variation}

Fig. 3 shows the EEM peaks and the fluorescence intensity changes of the EPS collected during different biodrying phases. In the $\mathrm{B} 62$ sample (day $0,20^{\circ} \mathrm{C}$, moisture content $=62.3 \%$ ), there were four obvious peak aggregates, A, B, C and D, at excitation/ emission (Ex/Em) wavelengths of $(222 / 340)$ with an intensity of 33.4 , Ex/Em of $(222 / 280)$ with an intensity of $31.8, \mathrm{Ex} / \mathrm{Em}$ of (278/280) with an intensity of 21.9, and Ex/Em of (260/460) with an intensity of 18.9 , respectively. Chen et al. (2003) defined excitation and emission boundaries into five regions. Peaks at $\mathrm{Ex} / \mathrm{Em}$ wavelengths of (200-250)/(330-380) and (200-250)/(200-330) are related to simple aromatic proteins. Peaks at Ex/Em wavelengths of $(250-280) /(200-380)$ are related to soluble microbial byproduct-like material. Peaks at Ex/Em wavelengths of (250-40 $0) /(380-500)$ and $(200-250) /(380-500)$ are related to humic acid-like and fulvic acid-like organics (Guo et al., 2014). Therefore, peaks $\mathrm{A}$ and $\mathrm{B}$ are in regions dominated by simple aromatic proteins such as tryptophan and tyrosine. The peak $C$ is in the region corresponding with soluble microbial byproducts. The peak $\mathrm{D}$ is in the region corresponding with humic acid-like and fulvic acid-like organics. These substances dominated the EPS of the initial biodrying sample.

In the $\mathrm{B} 60$ sample (day $4,56{ }^{\circ} \mathrm{C}$, moisture content $=59.8 \%$ ), peaks $A, B$, and $D$ significantly receded. The center fluorescence intensities of peaks $A, B$, and D decreased from 33.4 to $21.8(\mathrm{~A})$, 31.8-17.9 (B), and 18.9-9.0 (D). The center fluorescence intensity of region $C$ decreased from 21.9 to 19.0 . This indicates that aromatic proteins, humic acid-like and fulvic acid-like organics, degraded significantly during the first four days, and soluble microbial byproduct-like material degraded slightly as well. In the B52 sample (day $8,70^{\circ} \mathrm{C}$, moisture content $=52.2 \%$ ), peaks $\mathrm{A}$, $B$, and $C$ were barely present, with center fluorescence intensities at only $8.1,7.6$, and 6.1 , respectively. Conversely, the fluorescence intensity of peak D increased from 19.0 to 41.9 between days 4 and 8 . This suggests that the first thermophilic phase, aromatic pro- teins and soluble microbial byproduct-like material were degraded, while humic acid-like and fulvic acid-like organics were generated.

In the B45 sample (day $12,60{ }^{\circ} \mathrm{C}$, moisture content $=45.5 \%$ ), some insufficiently fermented SSBM in the pile corner was remixed with the rest of the pile by the mechanical turning on day 9 . The material then degraded, leading to the center intensities of peaks $\mathrm{A}, \mathrm{B}$, and $\mathrm{C}$ increasing from 8.1 to 21.3 (A), 7.6-21.4 (B), and 6.1-18.0 (C) between days 8 and 12 . The center fluorescence intensity of peak D decreased to 28.7 .

These results demonstrate the necessity of mechanical turning on d 9, which facilitates SSBM fermentation during the second thermophilic phase. In the B40 sample (day $16,42{ }^{\circ} \mathrm{C}$, moisture content $=40.3 \%$, peaks $\mathrm{A}, \mathrm{B}$, and $\mathrm{C}$ were almost invisible. In the B39 sample (day $20,20^{\circ} \mathrm{C}$, moisture content $=39.2 \%$ ), peak D was still observable with a center fluorescence intensity of 20.1. Peaks $\mathrm{A}, \mathrm{B}$ and $\mathrm{C}$ were barely present, with center fluorescence intensities decreasing to $7.7,7.9$, and 6.6 , respectively.

Large amounts of simple aromatic proteins and soluble microbial byproduct-like material, present in the EPS of the initial SSBM degraded significantly after sewage sludge biodrying. In contrast, humic acid-like and fulvic acid-like organics were generated in the EPS during the thermophilic phase; they were then moderately degraded during the cooling phase.

\subsection{Free water release}

Fig. 4 presents the dielectric constants and bound water contents of the biodrying samples at different stages. The dielectric constant of the bound water was approximately 3-4; the constant of the free water is approximately 81 at $20^{\circ} \mathrm{C}$ (Boyarskii et al., 2002). When the moisture content across different samples is constant, the higher dielectric constant indicates more free water in the sample. The relationship between free water content $(\theta)$ and the dielectric constant $(k)$ is as follows:

$\theta=0.0213 k^{3}-0.7615 k^{2}+9.5575 k+18.035 \quad R^{2}=0.99$

and the bound water contents were calculated based on Eqs. (3) and (4).

Therefore, when the biodrying temperature increased from $20^{\circ} \mathrm{C}$ to $70^{\circ} \mathrm{C}$, the dielectric constant increased from 9.13 to 15.52 , indicating that more free water was released in the SSBM as biodrying continued. Fig. 4 a shows that as the biodrying temperature increased, the second reflection angle became rounder and delayed, due to the increasing percentage of free water in the SSBM. Fig. 4b shows that when the temperature increased from $20^{\circ} \mathrm{C}$ to $40^{\circ} \mathrm{C}$, the slope of the dielectric constant increase was stable, with the constant just increasing from 9.13 to 10.23 and the bound water content decreasing from $14.2 \%$ to $11.6 \%$. When the temperature increased from $40^{\circ} \mathrm{C}$ to $50^{\circ} \mathrm{C}$, the slope was a little steep, with the constant increasing from 10.23 to 11.42 and the bound water content decreasing from $11.6 \%$ to $9.8 \%$; when the temperature increased from $50{ }^{\circ} \mathrm{C}$ to $60^{\circ} \mathrm{C}$, the slope significantly steepened, with the constant increasing from 11.42 to 15.28 and the bound water content decreasing from $9.8 \%$ to $5.9 \%$. When the temperature increased from $60^{\circ} \mathrm{C}$ to $70^{\circ} \mathrm{C}$, the slope leveled again, with the constant just increasing from 15.28 to 15.52 and the bound water content decreasing from $5.9 \%$ to $4.9 \%$.

These results highlight the importance of temperature in transforming bound water to free water. As biodrying temperature increased to $40^{\circ} \mathrm{C}$, a small amount of bound water was transformed into free water. When the temperature exceeded $40^{\circ} \mathrm{C}$, a greater amount of free water was released. The increase in biodrying temperature from $50{ }^{\circ} \mathrm{C}$ to $60^{\circ} \mathrm{C}$ defined the start of the thermophilic phase (U.S. Environmental Protection Agency, 1993). 

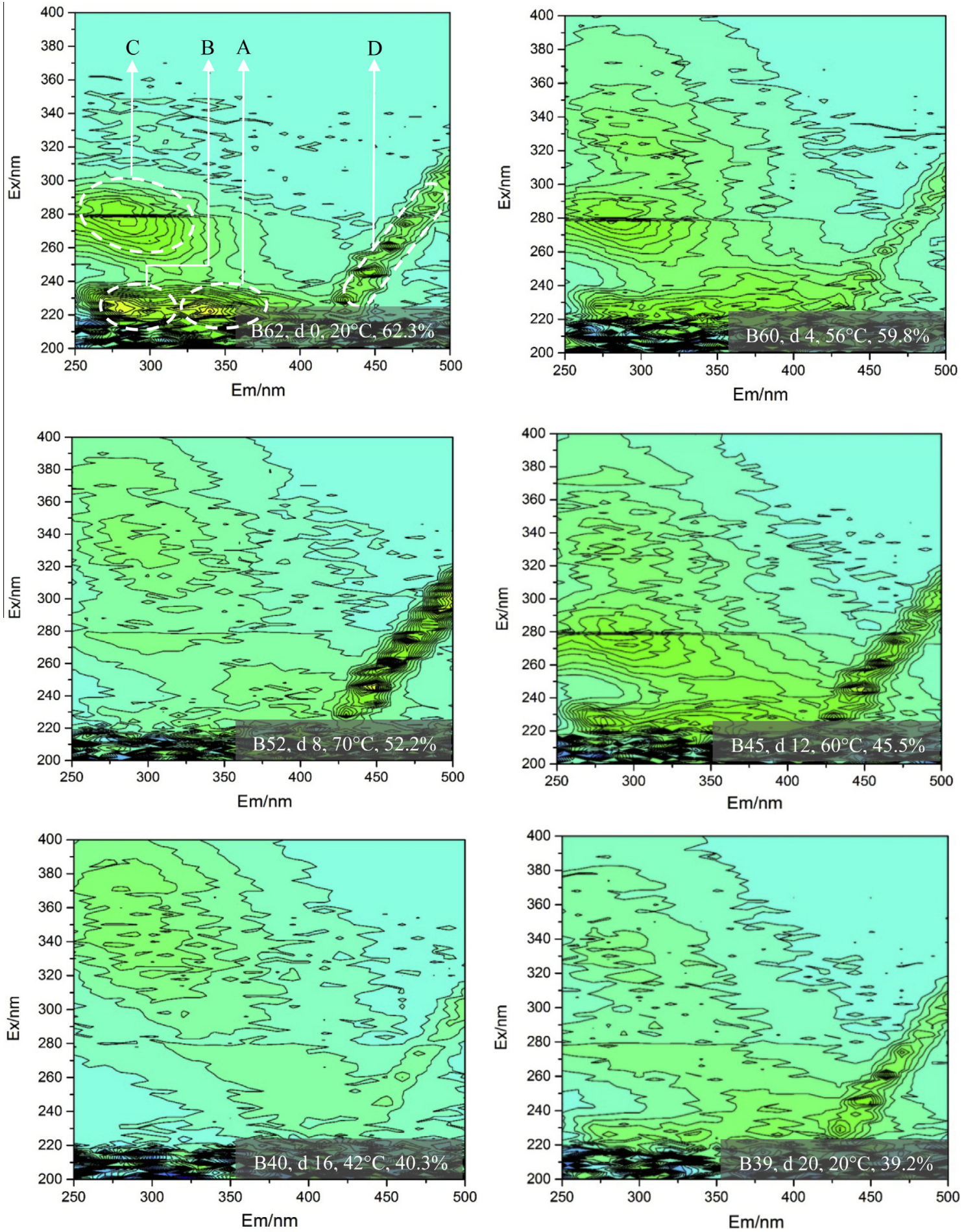

Fig. 3. Excitation and emission matrix spectra of extracellular polymeric substances in sewage sludge biodrying material at different phases.

This phase saw a significant increase in the transformation of bound water to free water, with a decrease in the bound water content from $9.8 \%$ to $5.9 \%$. When the biodrying temperature increased to $70{ }^{\circ} \mathrm{C}$, the SSBM had already been biodried at a high temperature for a period of time; as such, the water transformation remained stable, with the dielectric constant and bound water content steady at 15.52 and $4.9 \%$, respectively. This result suggests that the thermophilic phase is critical in transforming the water from bound to free form in SSBM.

\subsection{Property alteration with implication to water removal}

It is also important to consider an integrative analysis of the SEM, TDR, and EEM results. In the raw SSBM, the surface was compact and viscous (Fig. S1, B62), associated with the EPS composition of many aromatic proteins as tryptophan and tyrosine, and soluble microbial byproducts as protein-like materials (Fig. 3, B62); the bound water content is $14.2 \%$, which is calculated based on the dielectric constant of the raw SSBM (Fig. 4). This results in 

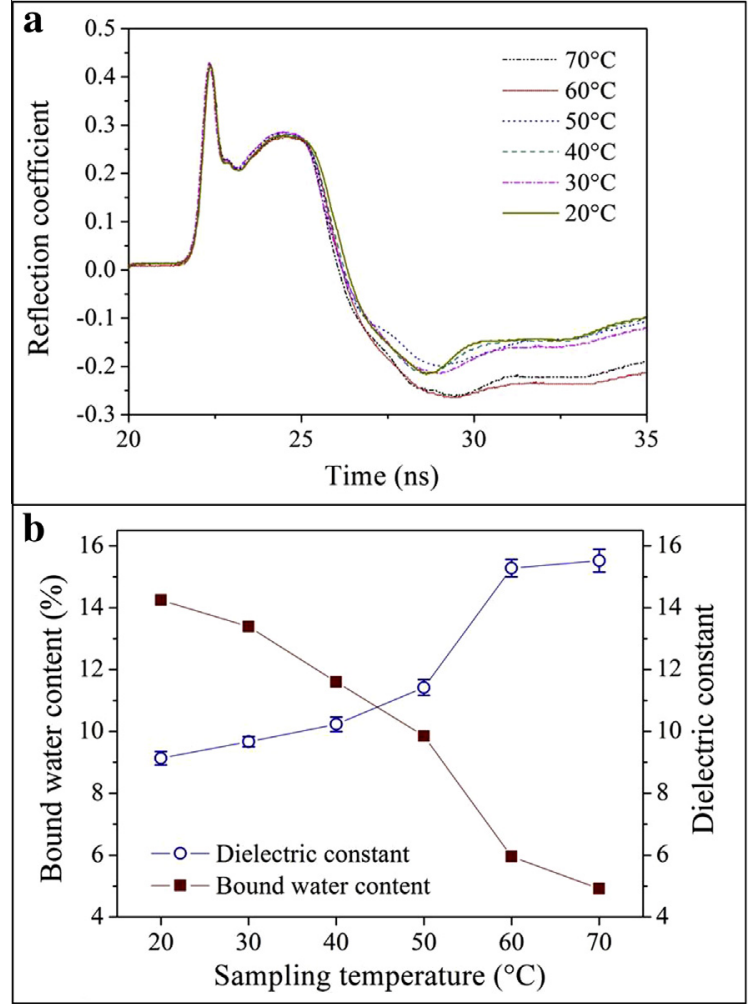

Fig. 4. Dielectric constant and calculated bound water content of sewage sludge biodrying material collected at different temperatures. Measurements were conducted at $20^{\circ} \mathrm{C}$. a - Waveforms in time domain reflectometry; b - Bound water content and dielectric constant values.

poor dewaterability, demonstrated by the lower water removal at the beginning of the biodrying (Fig. 2).

As biodrying proceeded, the SSBM surface became porous and stratified (Fig. S1, B60-B39), and the aromatic proteins and soluble microbial byproducts in the EPS degraded (Fig. 3, B60-B39), particularly during the thermophilic phase. The sludge flocs are highly centralized in the dewatered sludge cake, and the organic degradation in the EPS can result in the decomposition of floc structures (Dai et al., 2013). The dielectric constant of SSBM increased as biodrying proceeded (Fig. 4), indicating the significant transformation of bound water to free water in the SSBM. Especially when the temperature increased from $50^{\circ} \mathrm{C}$ to $60{ }^{\circ} \mathrm{C}$, the dielectric constant increased from 11.42 to 15.28 and the bound water content decreased from $9.8 \%$ to $5.9 \%$; therefore, the pile temperature of $50{ }^{\circ} \mathrm{C}$ is critical for the free water release during biodrying. Besides, the peak of free water release is consistent with that of water removal in the biodrying pile. After the self-heating of the pile on day 3, water removal increased, with the water removal rate peaking during the first thermophilic phase. The water removal rate reached $12.8 \%$ on day 5 (Fig. 2), with a total removal rate of $62 \%$, indicating great dewaterability. Biodrying converted the EPS composition and released free water, improving SSBM dewaterability.

In the final biodrying product (Fig. S1, B39), the presence of microbes showed more numerous surface irregularities, indicating the maturity of the final biodrying product (Kumar et al., 2014). Aromatic proteins and soluble microbial byproduct materials were significantly disaggregated (Fig. 3, B39) by microbes when the biodrying ended. In contrast, the process generates humic acidlike and fulvic acid-like materials. Therefore, the aromatic proteins, soluble microbial byproducts, humic acid-like substances and fulvic acid-like substances in the SSBM were found to have different conversion patterns. The above results suggested that as biodrying processed, the decomposition of floc structures occurred and humification degree increased. The water removal rate significantly declined during the cooling phase, approaching zero. As a consequence, the biodrying process modified the SSBM morphological structure, degraded the aromatic proteins and soluble microbial byproducts to promote the floc decomposition, and generated humic acid-like and fulvic acid-like materials, which benefit land use. Accompanied with the decomposition of floc structures, a significant amount of bound water is transformed into free water, improving water removal.

\section{Conclusions}

Water removal during the first thermophilic phase accounted for $62 \%$ of total water removal; there was an additional $28 \%$ water removal during the second thermophilic phase. Biodrying creates a hollow and stratified sludge structure with smoother edges, degrades aromatic proteins and soluble microbial byproducts in the EPS, and transforms bound water to free water. The structure modification, EPS conversion and free water release facilitate water removal during biodrying process.

\section{Acknowledgements}

This study was funded by the National Natural Science Foundation of China (Grant No. 41401538), the China Scholarship Council (Grant No. 201608330125) and the Zhejiang Provincial Natural Science Foundation of China (Grant No. LQ14D010001), and it was sponsored by the K.C. Wong Magna Fund at Ningbo University.

\section{Appendix A. Supplementary data}

Supplementary data associated with this article can be found, in the online version, at http://dx.doi.org/10.1016/j.biortech.2016.05. 102.

\section{References}

Basuvaraj, M., Fein, J., Liss, S.N., 2015. Protein and polysaccharide content of tightly and loosely bound extracellular polymeric substances and the development of a granular activated sludge floc. Water Res. 82, 104-117.

Boyarskii, D.A., Tikhonov, V.V., Komarova, N.Y., 2002. Model of dielectric constant of bound water in soil for applications of microwave remote sensing. Prog. Electromagn. Res. 35, 251-269.

Cai, L., Chen, T.B., Gao, D., Yu, J., 2016. Bacterial communities and their association with the bio-drying of sewage sludge. Water Res. 90, 44-51.

Cai, L., Gao, D., Chen, T., Liu, H., Zheng, G., Yang, Q., 2012. Moisture variation associated with water input and evaporation during sewage sludge bio-drying. Bioresour. Technol. 117, 13-19.

Chen, W., Westerhoff, P., Leenheer, J.A., Booksh, K., 2003. Fluorescence excitationemission matrix regional integration to quantify spectra for dissolved organic matter. Environ. Sci. Technol. 37 (24), 5701-5710.

Dai, X., Luo, F., Dai, L., Dong, B., 2013. Degradation of extracellular polymeric substances (EPS) in anaerobic digestion of dewatered sludge. Int. Symp. Environ. Sci. Technol. 18, 515-521.

Guo, L., Lu, M.M., Li, O.Q., Zhang, J.W., Zong, Y., She, Z.L., 2014. Three-dimensional fluorescence excitation-emission matrix (EEM) spectroscopy with regional integration analysis for assessing waste sludge hydrolysis treated with multienzyme and thermophilic bacteria. Bioresour. Technol. 171, 22-28.

He, P.J., Zhao, L., Zheng, W., Wu, D., Shao, L.M., 2013. Energy balance of a biodrying process for organic wastes of high moisture content: a review. Dry. Technol. 31 (2), 132-145.

Huang, J., Yang, Z.H., Zeng, G.M., Wang, H.L., Yan, J.W., Xu, H.Y., Gou, C.L., 2015. A novel approach for improving the drying behavior of sludge by the appropriate foaming pretreatment. Water Res. 68, 667-679.

Huiliñir, C. Villegas, M., 2015. Simultaneous effect of initial moisture content and airflow rate on biodrying of sewage sludge. Water Res. 82, 118-128.

Kumar, D.S., Kumar, P.S., Rajendran, N.M., Kumar, V.U., Anbuganapathi, G., 2014. Evaluation of vermicompost maturity using scanning electron microscopy and paper chromatography analysis. J. Agric. Food Chem. 62 (13), 2738-2741.

Kurt, M., Aksoy, A., Sanin, F.D., 2015. Evaluation of solar sludge drying alternatives by costs and area requirements. Water Res. 82, 47-57. 
Li, H.S., Wen, Y., Cao, A.S., Huang, J.S., Zhou, Q., 2014. The influence of multivalent cations on the flocculation of activated sludge with different sludge retention times. Water Res. 55, 225-232.

Li, X., Dai, X., Yuan, S., Li, N., Liu, Z., Jin, J., 2015. Thermal analysis and 454 pyrosequencing to evaluate the performance and mechanisms for deep stabilization and reduction of high-solid anaerobically digested sludge using biodrying process. Bioresour. Technol. 175, 245-253.

Li, X.Y., Yang, S.F., 2007. Influence of loosely bound extracellular polymeric substances (EPS) on the flocculation, sedimentation and dewaterability of activated sludge. Water Res. 41 (5), 1022-1030.

Liu, B., Wei, Q., Zhang, B., Bi, J., 2013. Life cycle GHG emissions of sewage sludge treatment and disposal options in Tai Lake Watershed, China. Sci. Total Environ. 447, 361-369.

Nadler, A., Green, S.R., Vogeler, I., Clothier, B.E., 2002. Horizontal and vertical TDR measurements of soil water content and electrical conductivity. Soil Sci. Soc. Am. J. 66 (3), 735-743.

Navaee-Ardeh, S., Bertrand, F., Stuart, P.R., 2010. Key variables analysis of a nove continuous biodrying process for drying mixed sludge. Bioresour. Technol. 101 (10), 3379-3387.

Noborio, K., 2001. Measurement of soil moisture content and electrical conductivity by time domain reflectometry: a review. Comput. Electron. Agric. 31 (3), 213237.

Rada, E.C., Ragazzi, M., 2014. Selective collection as a pretreatment for indirect solid recovered fuel generation. Waste Manage. 34 (2), 291-297.

Rada, E.C., Istrate, I.A., Ragazzi, M., 2009. Trends in the management of residual municipal solid waste. Environ. Technol. 30 (7), 651-661.

Raynaud, M., Vaxelaire, J., Olivier, J., Dieudé-Fauvel, E., Baudez, J.C., 2012 Compression dewatering of municipal activated sludge: effects of salt and $\mathrm{pH}$. Water Res. 46 (14), 4448-4456.

Schwartz, B.F., Schreiber, M.E., Pooler, P.S., Rimstidt, J.D., 2008. Calibrating accesstube time domain reflectometry soil water measurements in deep heterogeneous soils. Soil Sci. Soc. Am. J. 72, 917-930.
Song, Y., Zheng, G., Huo, M., Zhao, B., Zhou, L., 2014. Extracellular polymeric substances and bound water drastically affect bioleached sludge dewaterability at low temperature. Environ. Technol. 35 (20), 2538-2545.

Stasta, P., Boran, J., Bebar, L., Stehlik, P., Oral, J., 2006. Thermal processing of sewage sludge. Appl. Therm. Eng. 26 (13), 1420-1426.

U.S. Department of Agriculture and U.S. Composting Council, 2001. Test Methods for the Examination of Composting and Compost. Edaphos International, Houston, TX.

U.S. Environmental Protection Agency, 1993. Standards for the Use or Disposal of Sewage Sludge; 40 CFR PART 503. U.S. Environmental Protection Agency, Washington, DC.

Velis, C.A., Longhurst, P.J., Drew, G.H., Smith, R., Pollard, S.J.T., 2009. Biodrying for mechanical-biological treatment of wastes: a review of process science and engineering. Bioresour. Technol. 100 (11), 2747-2761.

Vesilind, P.A., 1994. The role of water in sludge dewatering. Water Environ. Res. 66, $4-11$.

Winkler, M.K.H., Bennenbroek, M.H., Horstink, F.H., Loosdrecht, M.C.M.V., Pol, G.J.V. D., 2013. The biodrying concept: an innovative technology creating energy from sewage sludge. Bioresour. Technol. 147 (7), 124-129.

Wu, C.C., Huang, C.P., Lee, D.J., 1998. Bound water content and water binding strength on sludge flocs. Water Res. 32 (3), 900-904.

Yu, G.H., Tang, Z., Xu, Y.C., Shen, Q.R., 2011. Multiple fluorescence labeling and two dimensional FTIR-13C NMR heterospectral correlation spectroscopy to characterize extracellular polymeric substances in biofilms produced during composting. Environ. Sci. Technol. 45 (21), 9224-9231.

Zhao, L., Gu, W.M., He, P.J. Shao, L.M., 2010. Effect of air-flow rate and turning frequency on bio-drying of dewatered sludge. Water Res. 44 (20), 6144-6152.

Zhen, G.Y., Lu, X.Q., Wang, B.Y., Zhao, Y.C., Chai, X.L., Niu, D.J., Zhao, A.H., Li, Y.Y., Song, Y., Cao, X.Y., 2012. Synergetic pretreatment of waste activated sludge by $\mathrm{Fe}(\mathrm{II})$-activated persulfate oxidation under mild temperature for enhanced dewaterability. Bioresour. Technol. 124, 29-36. 